I. Yatchev, I. Balabozov, K. Hinov, I. Hadzhiev, V. Gueorgiev

\title{
INFLUENCE OF THE SHAPE OF THE INPUT PULSES ON THE CHARACTERISTICS OF HYBRID ELECTROMAGNETIC SYSTEM WITH MAGNETIC FLUX MODULATION
}

\begin{abstract}
Introduction. Nowadays, the accelerated development of materials and technologies and the finding of new ones is a prerequisite for the improvement of well-known electromagnetic constructions used in various devices, as well as for the development of new ones. New construction of hybrid electromagnetic system with magnetic flux modulation (HEMSMM) is studied. The construction is composed of: ferromagnetic frame with air gaps, input and output coils and permanent magnets. Two input coils connected to the pulsed power supply are used to change the path of the generated by the permanent magnets constant magnetic flux. Input pulses with different shapes are applied to the input coils and signals in the output coils are obtained and compared. The main purpose of the work is to find the shape of the input pulses which leads to higher output power in comparison with the other shapes. Methods. Finite element method and COMSOL software is used for computer modelling of the proposed construction, where coupled electromagnetic field - electric circuit analysis is carried out. Results. A mathematical and numerical 3D model of new HEMSMM construction is realised and studied. The model allows to calculate and compare power efficiency of the studied device, when input pulses with different shapes are applied. Practical value. The developed computer model enables the study of the HEMSMM and other electromagnetic devices at different operating modes. It can be further improved and used in the search for optimal parameters of a particular electromagnetic device. References 13, table 1, figures 13.
\end{abstract}

Key words: FEM modelling, hybrid electromagnetic system, magnetic flux modulation, permanent magnets.

Bступ. У наш час прискорене вдосконалення існуючих і винахід нових матеріалів та обладнання є необхідною умовою вдосконалення відомих електромагнітних конструкиій, щзо використовуються в різних пристроях, а також для розробки нових виробів. Досліджується нова конструкція гібридної електромагнітної системи з модуляцією магнітного потоку (ГЕСМММ). Конструкиія складається з: феромагнітної каркасу з повітряними зазорами, вхідних та вихідних котушок та постійних магнітів. Дві вхідні котушки, підключені до імпульсного джерела живлення, використовуються для зміни шляху постійного магнітного потоку, щяо створюється постійними магнітами. Вхідні імпульси різної форми подаються на вхідні котушки, а сигнали у вихідних котушках отримуються та порівнюються. Основна мета роботи - знайти форму вхідних імпульсів, щчо призводить до вищої вихідної потужності в порівнянні з іншими формами. Методи. Метод скінченних елементів та програмне забезпечення COMSOL використовуються для комп'ютерного моделювання запропонованої конструкиії, де проводиться аналіз зв'язаних електромагнітного поля та електричного кола. Результати. Реалізовано та досліджено математичну та числову тривимірну модель нової конструкиії ГЕСМММ. Модель дозволяє розрахувати та порівняти енергетичну ефективність досліджуваного пристрою, коли застосовуються вхідні імпульси різної форми. Практична цінність. Розроблена комп'ютерна модель дозволяе досліджувати ГЕСМММ та інші електромагнітні пристрої при різних режимах роботи. Вона може бути додатково вдосконалена та використана для пошуку оптимальних параметрів конкретного електромагнітного пристрою. Бібл. 13, табл. 1, рис. 13.

Ключові слова: моделювання методом скінченних елементів, гібридна електромагнітна система, модуляція магнітного потоку, постійні магніти.

Introduction. Energy efficiency in the creation of new devices and in the modernization of existing ones is one of the basic requirements laid down in their design. The need to increase device efficiency leads to continuous search for new constructive variants and application of new materials and technologies. In electromagnetic systems, a good opportunity to increase their energy efficiency and to improve their technical parameters is the application of permanent magnets by means of which the neutral electromagnetic actuators can be replaced with polarized ones. There are also electromagnetic systems in which the magnetic flux created by a permanent magnet $(\mathrm{PM})$ is redirected to parallel ferromagnetic paths using a control coil. The change of magnetic field in the system is used to generate electricity. Such devices are hybrid electromagnetic systems with magnetic flux modulation (HEMSMM).

The idea of creating a hybrid device that uses a magnetic flux of a permanent magnet in combination with a variable magnetic flux created by a coil is not new [1-3]. Some of these designs are only conceptual and not realized due to lack of available materials with suitable characteristics.

Many HEMSMM constructions with closed (without an air gap in the path of the magnetic flux) and open magnetic path (with one or more air gaps in the path of the magnetic flux) and their working principles are described in [1]. The patent application and patents of motionless magnetic generator are described in [2-6]. Electromagnetic construction with two input and two output coils and special microprocessor circuits are described in [2]. The electronic control system of that device ensures ferromagnetic resonance of the core. Several modifications of construction with built-in PM and airgaps with variable resistors is proposed in [3]. Construction with control coil that is positioned outside of the frame with main magnetic flux is presented in [4]. Combination of DC and AC current source are used for power feeding of the system. In [5], two PMs are placed close to the coil with magnetic core and airgap between them is controlled to achieve change in magnetic flux. A device with perforated disks inserted in the airgaps is presented in [6]. The control system is realized with simple multivibrators. In [7] main working principles of hybrid electromagnetic system are described and using of new nanocrystalline materials for better energy efficiency of such devices is proposed. A three-dimensional computer model of magnetic field is used for studying influence of geometry of permanent magnet over the

(c) I. Yatchev, I. Balabozov, K. Hinov, I. Hadzhiev, V. Gueorgiev 
energy efficiency of an electromechanical system in [8]. Basic theoretical principles and formulations related to electromagnetism and magnetic field are discussed in [9] and [10].

The goal of the paper is to study the influence of input pulses with different parameters, mainly their shape, on the characteristics of a new construction of HEMSMM. The obtained results from the FEM simulations are compared.

Studied construction. Previous research by the authors for HEMSMM device is published in [11], where an existing simple construction with one PM and two control coils is studied. Also, an experimental study with a prototype of the HEMSMM system was conducted by the authors in [12]. In the present paper, a new construction with two built-in permanent magnets (PMs) in ferromagnetic core is presented. The path of magnetic flux from the PMs is controlled with two input coils which are supplied with voltage pulses with different shapes. It is also possible to set different amplitude, frequency and filling factor of the voltage pulses. In the ferromagnetic core, where the input coils are mounted, two air gaps are included in the centre of the coils. Four output coils are connected to resistive load and the output power is determined.

In Fig. 1, the main parts of the studied construction are shown. They are:

- 1 - ferromagnetic frame;

- 2 - input (control) coil 1;

- 3 - input (control) coil 2;

- 4 - output (signal) coil 6;

- 5 - output (signal) coil 5;

- 6-output (signal) coil 4;

- 7 - output (signal) coil 3;

- 8 -permanent magnets;

- 9 - air gaps.

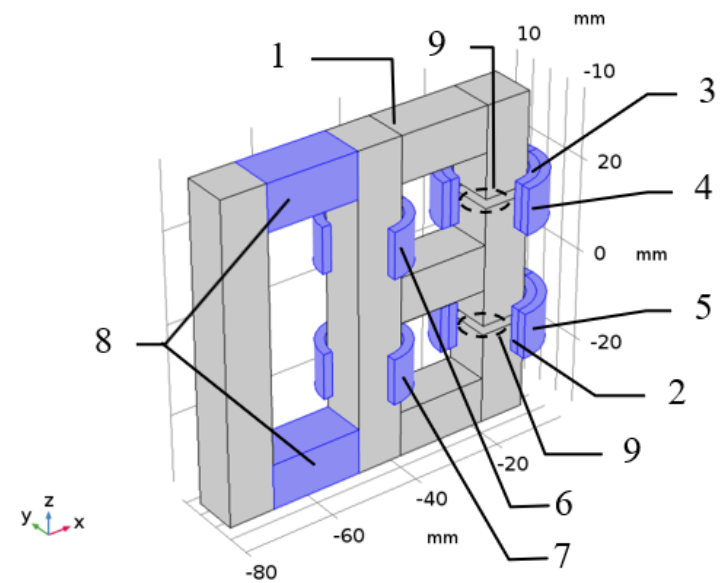

Fig. 1. Geometry of the studied new HEMSMM construction

Mathematical and numerical model. COMSOL Multiphysics [13] software is used for computer modelling, where coupled 3D electromagnetic field electric circuit problem is solved. Inductance and active resistance of the coils are obtained from electromagnetic field interface and are directly employed in electric circuit. An active load is connected to the output coil. The influence of the shape of the input (voltage) pulses applied to the control coils is studied. Simulations with sinusoidal, rectangular and triangular pulses are made. The electric circuit used in the simulations is given in Fig. 2.

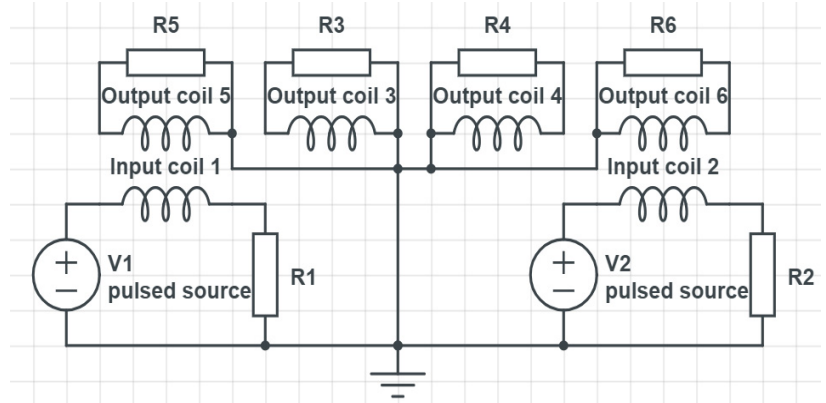

Fig. 2. Electric circuit used in the simulations

The mathematical model consists of one field equation and 6 circuit equations (one for each coil). The computer model with studied HEMSMM construction is solved in two steps. In the first step, the electric circuit does not participate and a stationary problem with respect to the electromagnetic field is solved. Results for the static magnetic field created only by the permanent magnets are achieved and are used as initial condition for the next step. In second step, time dependent coupled field-circuit problem is solved. Here, the coils are connected and powered by the electric circuit in Fig. 2.

All simulations can be also used to study the system for different frequencies and duty cycle of the input pulses.

Field equation for the first step (static case) is:

$$
\nabla \times\left(\mu_{0}^{-1} \nabla \times \boldsymbol{A}-\boldsymbol{M}\right)=0,
$$

where $\boldsymbol{A}$ is the magnetic vector potential; $\boldsymbol{M}$ is the magnetization; $\mu_{0}$ is the magnetic permeability of vacuum.

Field equation for time dependent step is:

$$
\sigma \cdot \frac{\partial \boldsymbol{A}}{\partial t}+\nabla \times\left(\mu_{0}^{-1} \nabla \times \boldsymbol{A}-\boldsymbol{M}\right)=N \cdot \frac{i(t)}{S},
$$

where $\sigma$ is the electrical conductivity of the material; $N$ is number of turns in the coil; $i$ is the current through the coil; $S$ is the coil cross section.

The circuit equations for the six coils are:

$$
\begin{gathered}
u_{1}(t)=R_{1} \cdot i_{1}(t)+\partial \Psi_{1} / \partial t \\
u_{2}(t)=R_{2} \cdot i_{2}(t)+\partial \Psi_{2} / \partial t \\
-\partial \Psi_{3} / \partial t=R_{3} \cdot i_{3}(t) \\
-\partial \Psi_{4} / \partial t=R_{4} \cdot i_{4}(t) \\
-\partial \Psi_{5} / \partial t=R_{5} \cdot i_{5}(t) \\
-\partial \Psi_{6} / \partial t=R_{6} \cdot i_{6}(t)
\end{gathered}
$$

where $u_{1}(t)$ and $u_{2}(t)$ are voltages of coil 1 and coil 2 respectively; $R_{1}$ to $R_{\mathbf{6}}$ are active resistances of the coils; $i_{1}(t)$ to $i_{6}(t)$ are currents through the coils; $\Psi$ is flux linkage.

Some of the main parameters used in computer modelling of the construction are:

- all coils are cylindrical with 100 turns made of copper conductor;

- the magnetic frames are of ferromagnetic material of $B-H$ curve presented in Fig. 3. The cross section of the frame is $10 \times 10 \mathrm{~mm}$; 
- the permanent magnets are modelled with relative permeability $\mu_{r}=1.05$ and coercive force of $970 \mathrm{kA} / \mathrm{m}$.

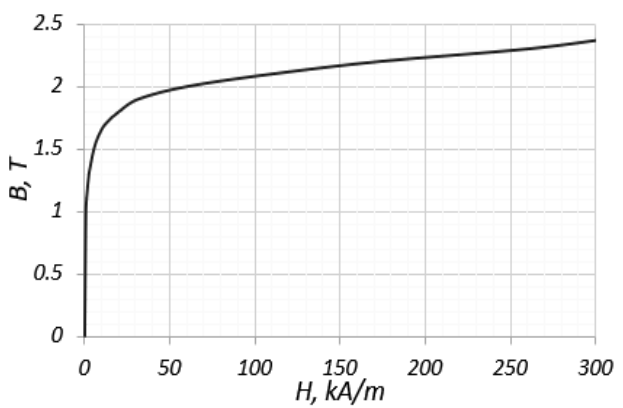

Fig. 3. $B$ - $H$ curve of used ferromagnetic material used in the modelling

Results from simulations. Distribution of the magnetic flux density of the studied construction, when the control coils are not energized is shown in Fig. 4. In this case the fluxes are due to PMs built in the ferromagnetic frame.

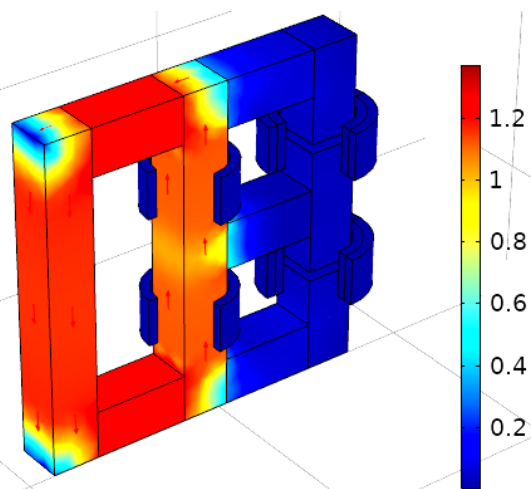

Fig. 4. Magnetic flux density of the studied HEMSMM construction, when the input coils are not energized

The flux density working point of the permanent magnet is close to the point of the remanent flux density and its variation is less than $1 \%$. The change of magnetic flux density in the system, when voltage pulses are applied to the input coil 1 and to input coil 2, is presented in Fig. 5.

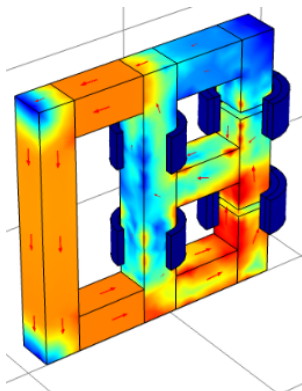

$a$

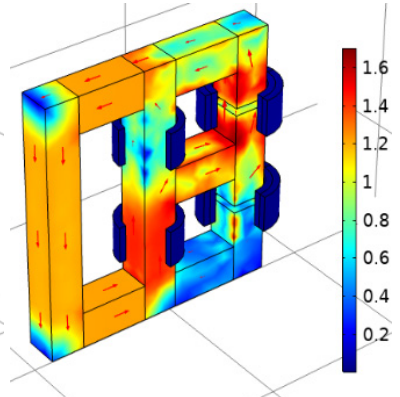

$b$

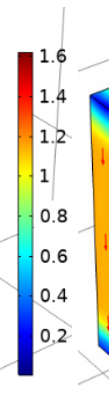

Fig. 5. Magnetic flux density of the studied HEMSMM construction:

a) power supply of input coil 1

b) power supply of input coil 2

In Fig. 6 to Fig. 8, results for the voltage of input coil 1 and output coil 5, when different shapes of input pulses are applied, are presented. Due to similarity, the results for the other coils are not given.

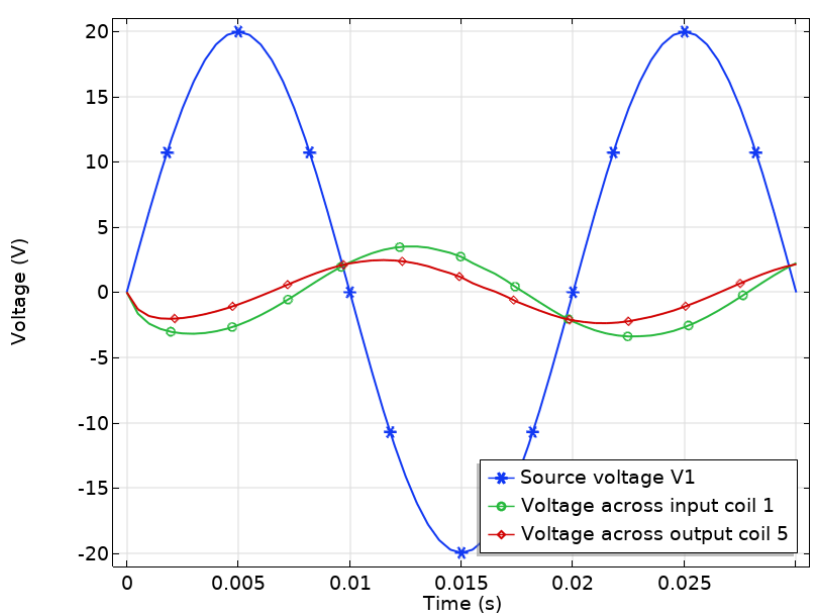

Fig. 6. Voltage of input coil 1 and output coil 5 with sinusoidal waveforms

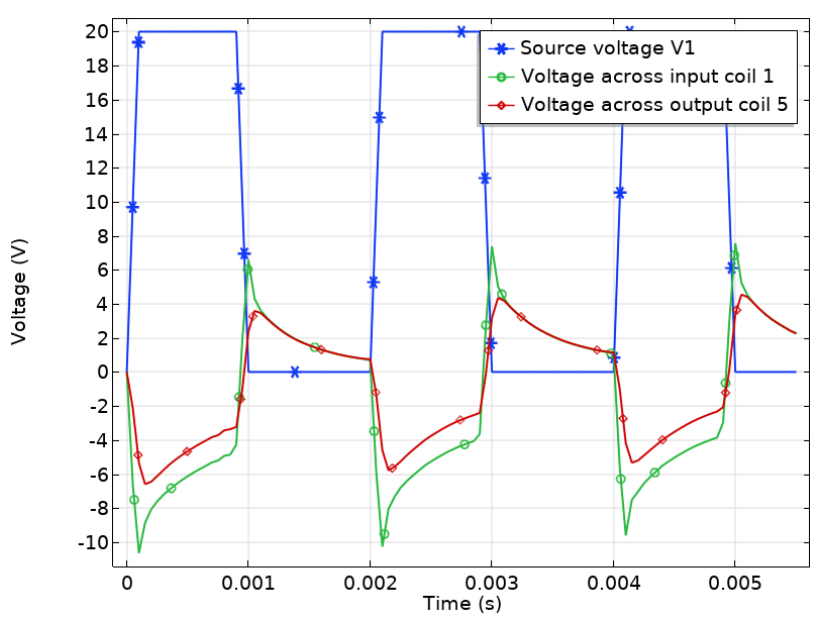

Fig. 7. Voltage of input coil 1 and output coil 5, pulses with rectangular shape

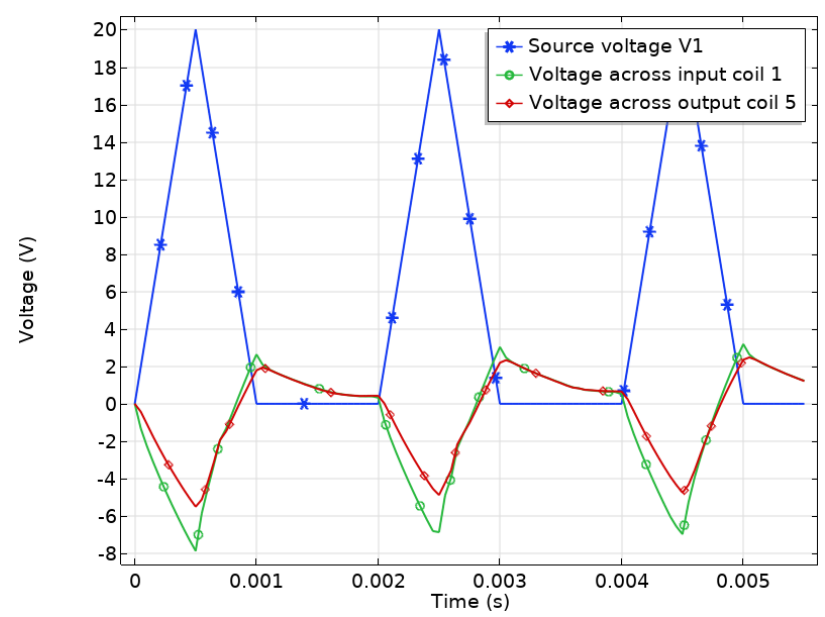

Fig. 8. Voltage of input coil 1 and output coil 5, pulses with triangular shape

Currents through input and output coils in the system for two of the cases (rectangular and triangular pulses) are given in Fig. 9 and Fig. 10. It is worth to note that the current through output coils 3 and 4 is closer to sinusoidal form when the input pulses are triangular, the reason for that is the slower changing of the magnetic fluxes in the magnetic core of that zone of the system, when triangular pulses are applied. 


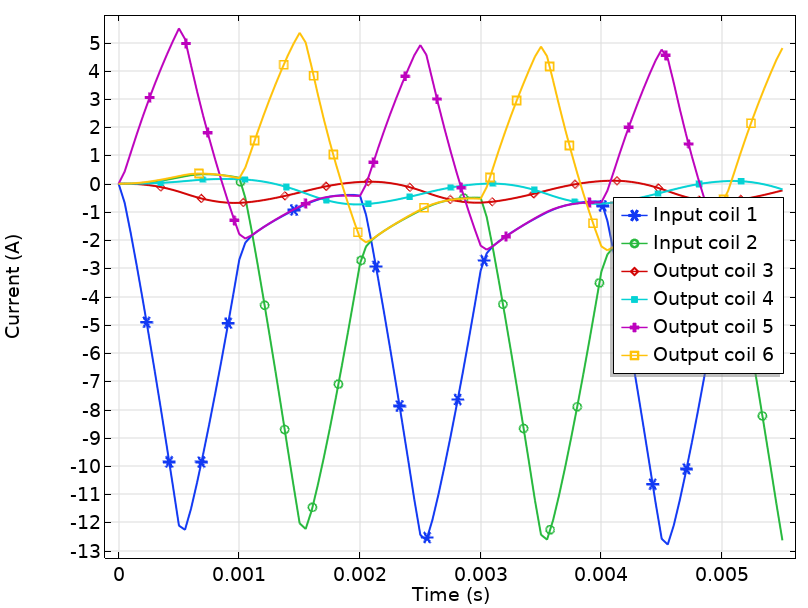

Fig. 9. Currents through the coils when triangular pulses are applied

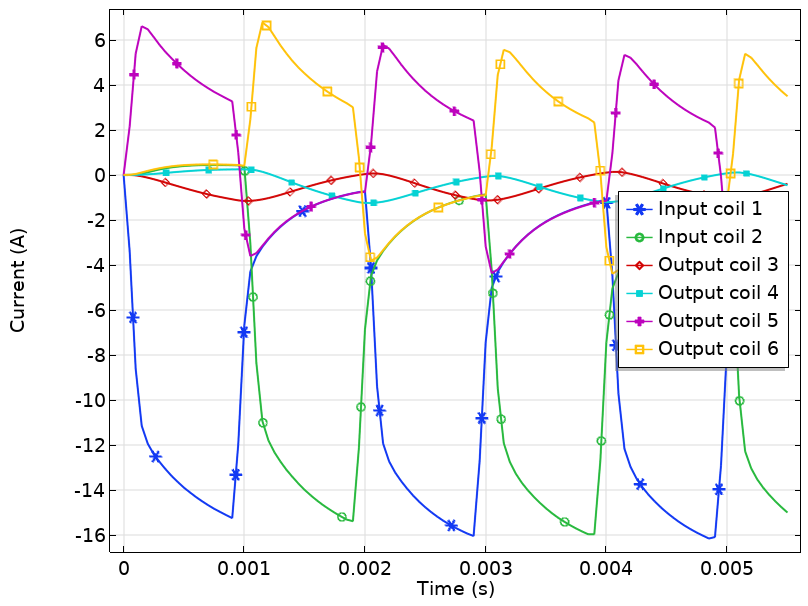

Fig. 10. Currents through the coils when rectangular pulses are applied

Results for the input and output power of each coil of the system and for the studied three different shapes (sinusoidal, rectangular and triangular) of the input pulses, are obtained. Some of the results are shown in Fig. 11 to Fig. 13.

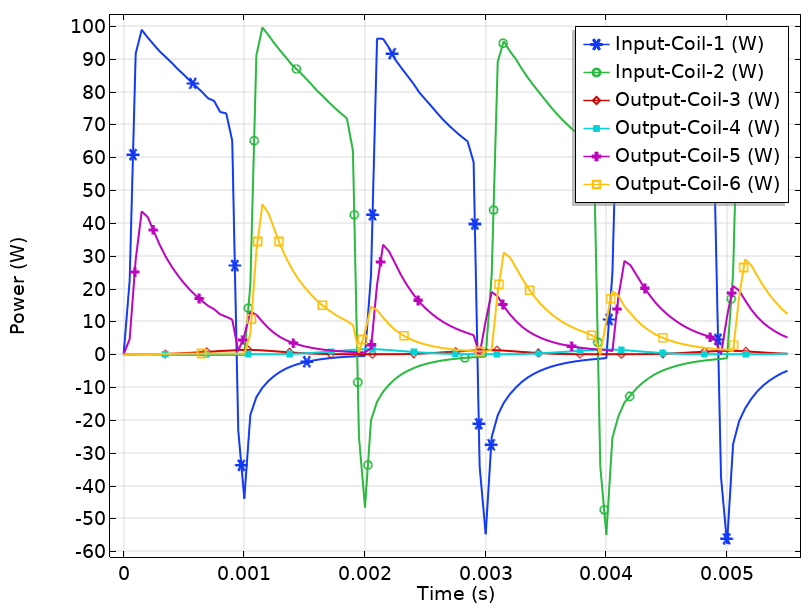

Fig. 11. Input and output power when rectangular pulses are applied

When rectangular pulses are used, the shape of output power does not match the input power shape. In the case with triangular pulses, the shapes of input and output power match better.

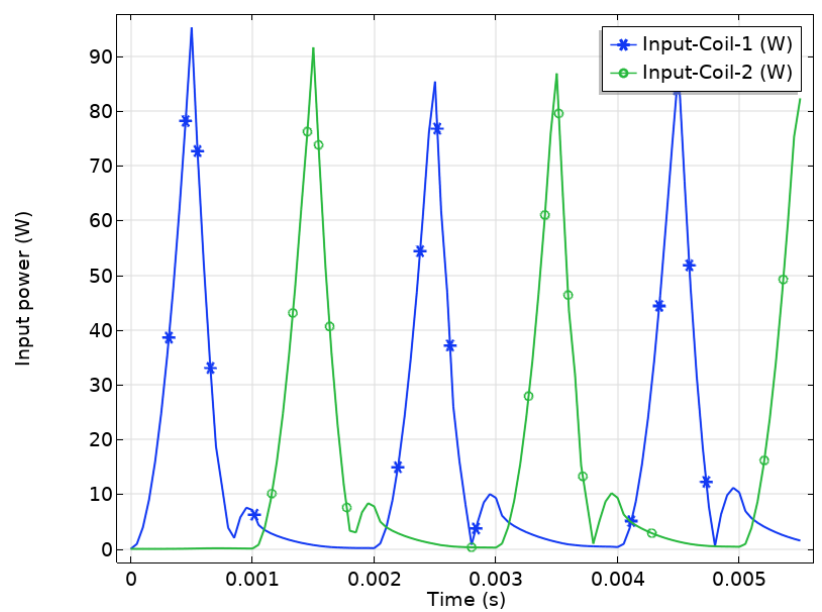

Fig. 12. Input power when triangular pulses are applied

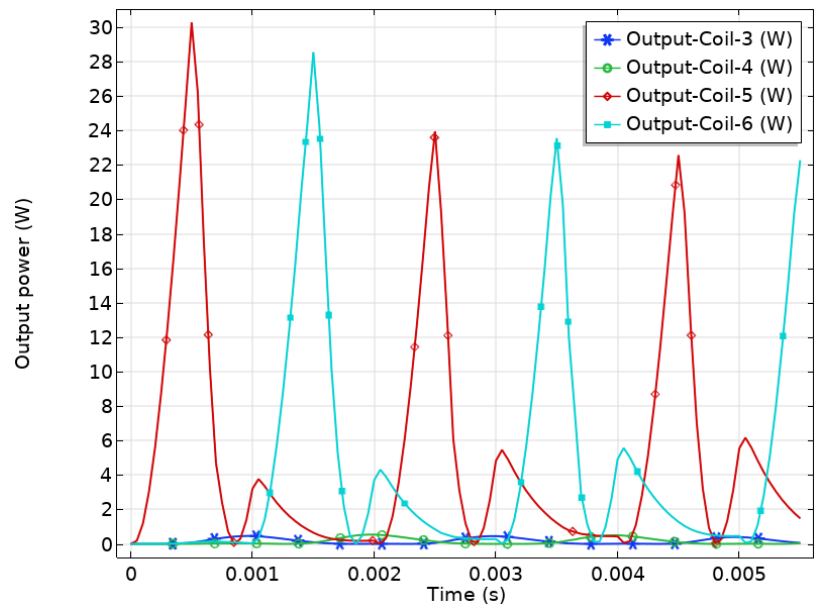

Fig. 13. Output power when triangular pulses are applied

The average input and output power of the coils is calculated and is presented in Table 1, where and comparison is made and efficiency of the system for input pulses with different shapes is achieved.

Table 1

Comparison of input and output power of the studied system

\begin{tabular}{|c|c|c|c|}
\hline $\begin{array}{c}\text { Shape of the } \\
\text { input power } \\
\text { pulse }\end{array}$ & $\begin{array}{c}\text { Average } \\
\text { input power } \\
\text { (coil 1 + 2) }\end{array}$ & $\begin{array}{c}\text { Average output } \\
\text { power (coils } \\
3+4+5+6)\end{array}$ & Efficiency \\
\hline Sinusoidal & $46,14 \mathrm{~W}$ & $8,10 \mathrm{~W}$ & $17,55 \%$ \\
\hline Rectangular & $60,69 \mathrm{~W}$ & $22,25 \mathrm{~W}$ & $36,66 \%$ \\
\hline Triangular & $24,44 \mathrm{~W}$ & $9,73 \mathrm{~W}$ & $39,82 \%$ \\
\hline
\end{tabular}

The table shows the results obtained for the average input and output power of the system under different shapes of the input power pulses.

\section{Conclusions.}

The developed computer model enables the study of the hybrid electromagnetic system with magnetic flux modulation at different operating modes. For the proposed construction, the influence of the shape of the input power pulses on the efficiency of the system is studied. From the results obtained for the studied pulse shapes, the best results with respect to the efficiency are obtained with triangular pulses. The developed computer models can also be used to investigate other parameters, as well as to optimize the design of such devices. 


\section{Acknowledgment.}

The present work is supported by the National Science Fund of Bulgarian Ministry of Education and Science, Project No. DN 17/13.

Conflict of interest. The authors declare that they have no conflicts of interest.

\section{REFERENCES}

1. Kunel H. Procedures and devices for energy production. Patent DE3024814, 1982.

2. Suarez J. Estatico processor electrical power. ES Patent $2265253 \mathrm{~B} 1,2008$.

3. Matsanov R. Pulse generator. Patent WO2010094993A1, 2010.

4. Tatevosian A.S., Tatevosian A.A., Dorokhin V.N Permanent magnet machine. RU Patent 2542322 C2, 2015.

5. Fridrich J. Electric power generation device. Patent CZ305224B6, 2015.

6. Gleich A. Permanent magnet-driven current generator. Patent application DE102014017612A1, 2016.

7. Karastoyanov D. Hybrid electromagnetic systems for energy efficiency of electrical systems. AIP Conference Proceedings, vol. 2022, 6 November 2018, art. no. 020016. doi https://doi.org/10.1063/1.5060696.

8. Leonov S.V., Zhiganov A.N., Kerbel'B.M., Fedorov D.F., Makaseev Y.N., Kremlev I.A. Analysis of the influence of permanent magnet geometry on the energy efficiency of electromechanical systems. Russian Physics Journal, 2016, vol. 59, no. 2, pp. 308-313. doi: https://doi.org/10.1007/s11182-016$\underline{0772-1 .}$.

9. Hacker V., Sumereder Ch. 5. The magnetic field. Electrical Engineering, Berlin, Boston, De Gruyter Oldenbourg, 2020, pp. 91-108. doi: https://doi.org/10.1515/9783110521115-005.

10. Gunther L. Electricity, Magnetism, and Electromagnetic Waves. The Physics of Music and Color, Springer, Cham, 2019. doi: https://doi.org/10.1007/978-3-030-19219-8 5.

How to cite this article:

Yatchev I., Balabozov I., Hinov K., Hadzhiev I., Gueorgiev V. Influence of the shape of the input pulses on the characteristics of hybrid electromagnetic system with magnetic flux modulation. Electrical Engineering \& Electromechanics, 2021, no. 3, pp. 3-7. doi: https://doi.org/10.20998/2074-272X.2021.3.01.
11. Yatchev I., Balabozov I., Hinov K., Minchev M., Gueorgiev V. Electromagnetic field analysis of a hybrid electromagnetic system with magnetic flux modulation with one permanent magnet and two collecting coils. 2018 20th International Symposium on Electrical Apparatus and Technologies (SIELA), 2018, pp. 1-4. doi: https://doi.org/10.1109/siela.2018.8447108.

12. Balabozov I., Tomov D., Yatchev I., Hadzhiev I., Brauer H. Experimental study of the influence of some parameters on the characteristics of hybrid electromagnetic system with magnetic flux modulation. 2020 21st International Symposium on Electrical Apparatus \& Technologies (SIELA), 2020, pp. 1-4. doi: https://doi.org/10.1109/siela49118.2020.9167093.

13. COMSOL Multiphysics 5.3 User's Guide, COMSOL, Inc., 2018.

Received 29.03.2021

Accepted 11.05.2021

Published 25.06.2021

Ivan Yatchev ${ }^{1}$, Doctor of Technical Sciences, Professor, Iosko Balabozov ${ }^{1}$ PhD, Associate Professor,

Krastyo Hinov ${ }^{1}, P h D$, Associate Professor,

Ivan Hadzhiev ${ }^{2}$, PhD, Assistant Professor,

Vultchan Gueorgiev ${ }^{1}$, PhD, Associate Professor,

${ }^{1}$ Technical University of Sofia,

8 Kl. Ohridski Blvd, 1000, Sofia, Bulgaria,

e-mail: yatchev@tu-sofia.bg (Corresponding author), i.balabozov@tu-sofia.bg,_k_hinov@yahoo.co.uk, vulchy@tu-sofia.bg

${ }^{2}$ Technical University of Sofia, Plovdiv Branch,

25 Tsanko Dyustabanov Str., 4000 Plovdiv, Bulgaria, e-mail: hadzhiev_tu@abv.bg 